\title{
Analysis of application of alternative drive systems for international heavy-duty transport on Wroclaw-Dresden-Prague routes
}

\author{
Maria Skrętowicz ${ }^{1, *}$, Zbigniew Sroka $^{1}$ \\ ${ }^{1}$ Wroclaw Unviesrity of Science and Technology, Faculty of Mechanical Engineering, Braci \\ Gierymskich 164, 51-640 Wrocław
}

\begin{abstract}
The depletion of the fossil fuels resources, significant increase of the air pollution caused by the use of internal combustion engines, and emission of carbon dioxide which is responsible for the greenhouse effect escalates the development of vehicle's alternative drive systems. Generally, the emphasis is given to the alternative fuels (natural gas $\mathrm{CNG}$, mixture of propane-butane gases LPG, hydrogen, alcohol fuels, biofuels) and hybrid or electric vehicles. Roads between large industrial and commercial centres, i.e. Wroclaw - Dresden - Prague, are used mainly by heavy-duty vehicles. Consequently, the contribution of the road transport to the ecological threat in this realm is significant. The objectives of this research were the assessment of the traffic volume and emission rate of exhaust gases caused by heavy-duty vehicles on the analysed roads and evaluation of the possibility of using existing and alternative drive systems in vehicles driving on the roads in the analysed region.
\end{abstract}

\section{Introduction}

Transport of goods is one of the most important aspects of both national and international economy. It enables the exchange of goods between economic centres. According to data from the Central Statistical Office of Poland, there are more than 3,000,000 trucks and almost 330,000 road tractors [1] registered in Poland. In the European Union the largest amount of goods in 2016 was transported in the countries such as Germany (especially the NordrheinWestfalen region) with 151 trilion tkm, and subsequently the United Kingdom, Spain, France, Italy, Poland, Belgium, the Czech Republic, the Netherlands, Portugal, Finland and Sweden [2].

Apart from the economic and social benefits, the transport (especially the road one) entails serious risks to the environment such as: accidents (threat to the health and life of humans and animals, spills and evaporation of transported substances, fuel and liquid consumables), noise and vibration of surface, not to mention the exhaust fumes emissions, including greenhouse gases, into the atmosphere [3]. According to the report published by The National Centre for Emissions Management (KOBiZE), in 2014 the transport was responsible for $14.06 \%$ of the nitrogen dioxide emission into the atmosphere in Poland [4].

\footnotetext{
*Corresponding author: maria.skretowicz@pwr.edu.pl
} 
Figure 1 shows the share of particular groups of motor vehicles in $\mathrm{CO} 2$ emission in Poland for 2014.

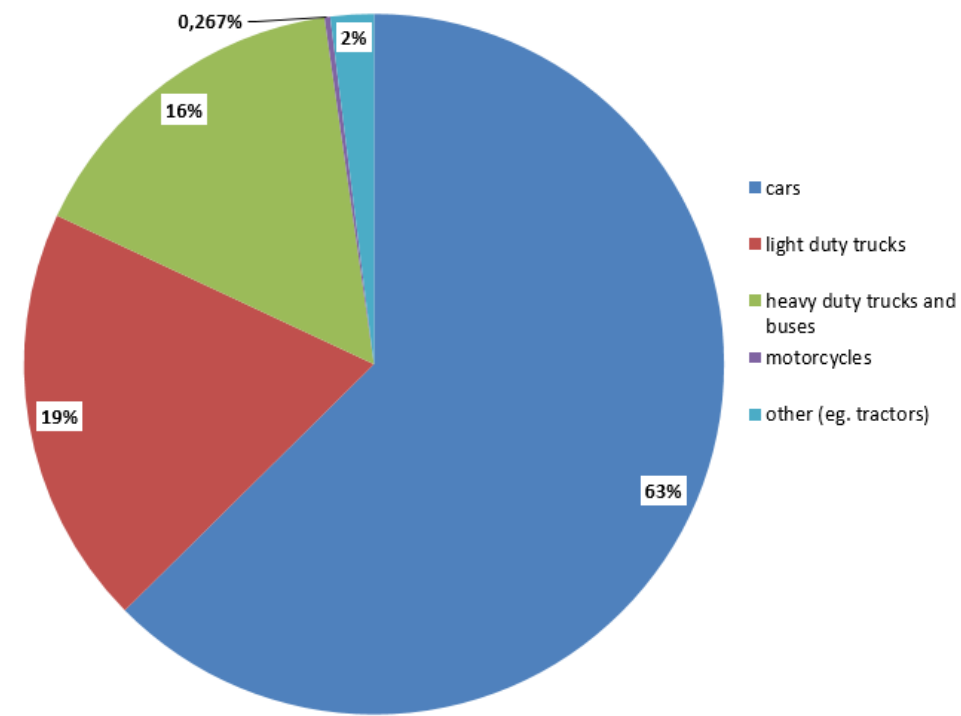

Figure 1 - The share of particular groups of motor vehicles in $\mathrm{CO}_{2}$ emission in Poland in 2014. Source: The National Centre for Emissions Management (KOBiZE)

Nowadays, the aim is to ensure that the vehicles are equipped with engines that comply with EURO standards which were introduced by the European Union. They define the permitted amount of pollutants emitted into the atmosphere. However, the range of trucks and commercial vehicles in terms of the year of production is so large that one cannot clearly determine the concentrations of toxic compounds in the air at the designated area. The reduction of toxic exhaust emissions and carbon dioxide is carried out in various ways, starting from constructional design solutions (e.g. Variable Valve Timing) through the use of aftertreatment systems (e.g. three-way catalyst, selective catalytic reduction) and ending with alternative fuels and drives. Seeing that, some researches on the possibility of using fuel cell electric trucks across the commercial medium and heavy duty vehicles have been conducted [5]. The studies have shown that aforementioned implementations are possible for many types of vehicles without a loss of engine's performance (which is very important for longdistance transport). Moreover, in many cases these parameters are improved while introducing the analyzed alternative propulsion systems.

One of the solutions that allow the reduction of negative impact of motorization on the environment in a quick and effective way is the power supply of the vehicle with compressed natural gas $(\mathrm{CNG})$. $\mathrm{CNG}$ fuel is easily accessible and can be used as the alternative fuel for both diesel and petrol $[6,7]$. In order to supply the combustion engine with natural gas, one only needs to equip the engine with a special installation. Many truck manufacturers already have such equipped vehicles in their offer (e.g. Fiat, Iveco, MAN, Scania and Mercedes). Needless to say that trucks and vans equipped with natural gas installation would contribute to the significant reduction of emission of harmful substances into the atmosphere. Additionally,

it would decrease the noise level, since $\mathrm{CNG}$ engines operate quieter than conventional ones.

The aim of this study is to analyse the possibility of using natural gas as the fuel for vehicles hauling goods on selected routes connecting the three major economic centres: Wroclaw, Dresden and Prague. 


\section{Characteristic of the transport and infrastructure in the analysed region}

So as to conduct the research, the authors of this work chose routes that connect three large European cities that are located in the neighbourhood: Wroclaw (Poland), Dresden (Germany) and Prague (the Czech Republic).

The goods produced in these centres are received and delivered to the other city with the use of road transport. The market for services is also more developed than in smaller towns. As a result, the greatest concentration of vehicles (passenger cars, light duty vehicles, LCVs, as well as heavy duty vehicles and HDVs) is observed in the vicinity of large cities. It contributes to the higher concentration of air pollution in these areas.

As far as the analysed routes are concerned, many trucks transporting goods between different centres of trade can be observed. It should be noted that traffic intensity on these routes is various, depending on many factors such as: the time of day, day of week and direction of motion. Moreover, the working time requirements of professional drivers have an impact on the amount of moving vehicles.

The vehicles were counted in three measuring points on every selected road. They were toted up based on the following classes:

- Class I - delivery trucks with technically permissible maximum laden mass not greater than 3.5 tones,

- Class II - vehicles with technically permissible maximum laden mass greater than 3.5 tones but not exceeding 12 tones,

- Class III - trucks with technically permissible maximum laden mass exceeding 12 tones.

Within each class of vehicles, trucks were divided in terms of the producer and the type of fuel. It enabled the estimation of toxic emissions into the atmosphere. Thus, the level of air pollution in the area caused by vehicles could be assessed. During the study, petrol stations on the analysed routes and types of fuel which they offer have been listed. Figure 2 shows a map with marked routes that have been analysed. The A4 highway was a route from Wroclaw to Dresden. When it comes to the Dresden-Prague connection, A17 motorway on the German side and the road E55 in the Czech Republic were evaluated. Last but not least, the road section from Prague to Wroclaw was analysed based on the E65 road (in the direction of Jelenia Góra) and then a short stretch of the A4 motorway from "Kostomłoty" exit.

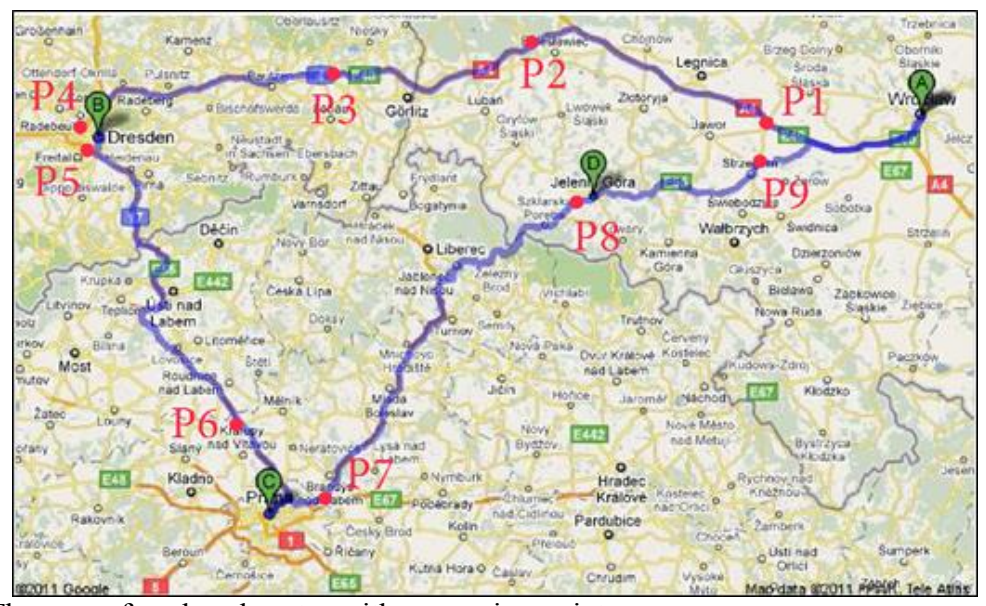

Figure 2 - The map of analysed routes with measuring points. 
Measurements were carried out in two days (28 ${ }^{\text {th }}$ and $29^{\text {th }}$ April 2010) between 9am and $2 \mathrm{pm}$ on the Wroclaw - Dresden road. In case of Dresden - Prague route analysis was conducted between 3:50pm-7:30pm and on Prague - Wroclaw stretch between 6:30 am and midnight. Figure 3 shows a quantitative summary of vehicles in all measuring points. At each point the vehicles were counted for 30 minutes in both directions of travelling.

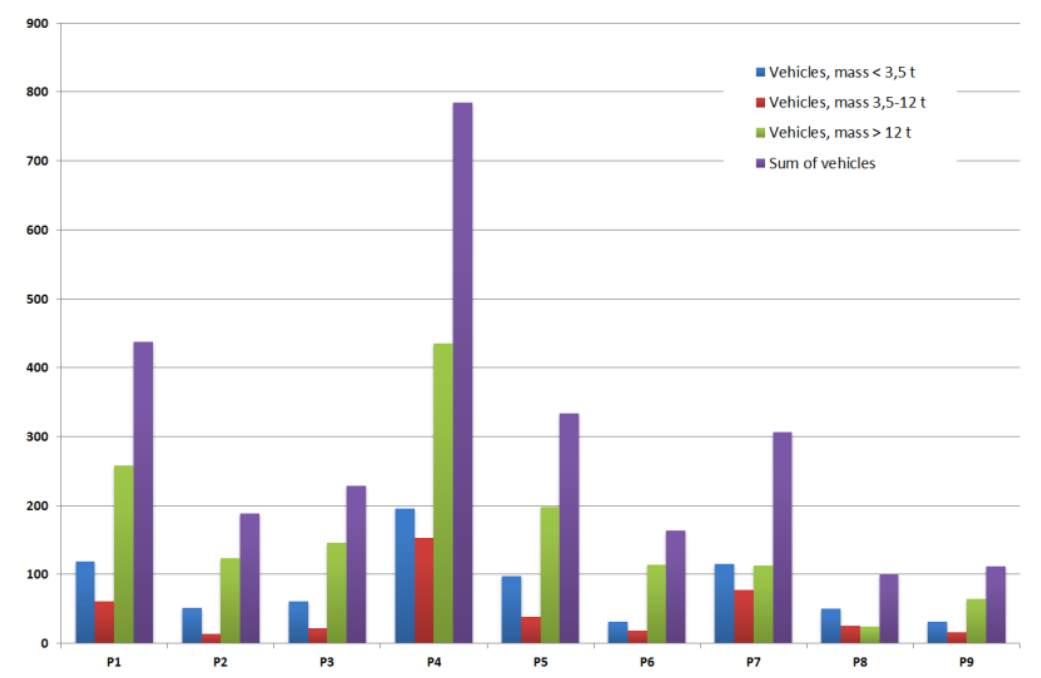

Figure 3 - The number of vehicles measured at the measurement points

As it is shown in Figure 3, the largest number of vehicles was measured in the vicinity of large cities (P1, P4, P5, P7 points). Moreover, the largest share of vehicles belongs to the heavy goods vehicles with a total gross vehicle mass (GVM) exceeding 12 tonnes and then to light duty vehicles designed to carry small loads.

Wroclaw and Dresden are directly connected with the A4 motorway on the Polish side and the BAB 4 motorway on the German side. This route is $270 \mathrm{~km}$ long, including $165 \mathrm{~km}$ length on the Polish side. The whole stretch of the route is free of charge. Measurements on this distance were carried out on 3 points: 2 points on the Polish side (P1 and P2) and 1 point on the German side (P3). Conducting research at two points on the Polish side enabled the verification of the number of vehicles that cross Polish-German border on the route. Additionally, it determined the amount of automobiles that head to A18 motorway (point P1 was located in front of the exit of the A18 motorway and the point P2 just behind the exit Figure 2).

As far as the point P1 is concerned, it was located at the Pietrzykowice. It is the first exit of the motorway on the Wroclaw - Jędrzychowice section, $43 \mathrm{~km}$ from Wroclaw. The research was conducted between 9:00-9:30am. At that point, the heaviest traffic on that route has been recorded. There may be two reasons for this fact. Firstly, the test was performed in a relatively close distance from Wroclaw, which is a large economic centre. As it was already mentioned, heavy traffics are in the vicinity of important economic centres. Secondly, the time when the research was conducted is known as the peak traffic hours. When it comes to the point P2, it was located in the meadow, about $45 \mathrm{~km}$ from the state border, behind the junction of A18 motorway. In addition, the measurement at point P2 was performed between 11:20am and 11:50 am. The level of traffic at P2 was less than half at the point P1. It could be due to the fact that the part of the vehicles was heading to A1 8 motorway. Moreover, P2 is remote from major economic centre. On the other hand, point P3 was located in Germany, $15 \mathrm{~km}$ from Bautzen. The measurement was performed between 1:00-1:30pm. At that point, the number of vehicles remained at a similar (slightly higher) level than the point $\mathrm{P} 2$, which is 
still significantly lower than at point P1. It is primary due to the remote distance from the large industrial centre, as it was in the $\mathrm{P} 2$ case.

On the basis of the Figure 4, one can conclude that the vast majority (more than $60 \%$ ) of all types of vehicles on this route were trucks with GVW exceeding 12 tons. Almost 30\% of automobiles were delivery trucks and the rest of the vehicles were those with GVW ranging from 3.5 till 12 tones. The researchers identified a total of 18 petrol stations on the road. The location of some stations requires getting off the freeway. The majority of petrol stations offer fuels such as diesel oil (ON), 95-octane and 98-octane gasoline. Some of them sale LPG and bio-additives fuel.

Another stretch of analysis was the Dresden-Prague route which is $148 \mathrm{~km}$ long. The first measurement point on that road (point P4) was still on the BAB 4, at the exit from Dresden and in the direction of Prague following the signs. At that point the measurement was performed between 4:00-4:30pm. Because of the rush hour and the fact that it was a point located in the nearby of the exit road form the big economic centre, which is Dresden, the measured traffic volume at that point was the greatest of all measuring points. Another point (P5) was located on BAB17. Similarly to the previous route, the greater the distance from the big economic centre, the lower the number of vehicles is around. It decreased by almost half comparing to the point P4. However, it was slightly lower than at the point P1 (not far from Wroclaw). Due to the inconveniences on the road (the reconstruction of road infrastructure and consequently traffic congestions) in the Czech Republic, the last measurement was taken at a point P6. It is located just before the drive-in entry to the capital of the Czech Republic, i.e. Prague. This measurement was conducted in the evening, between 7:00pm and 9:30pm. It could explain the small number of vehicles in that area, comparing to the previous points, despite the short distance from Prague.

On the basis of the results shown in Figure 4, one can detect that Dresden is a thriving economic centre which is burdened with a very high flow of vehicles that transport goods.

During the measurement conducted at the point P4 (in close proximity to Dresden), researchers counted more vehicles than at the points P1 (near Wroclaw) and P6 (near Prague) cumulatively. However, it should be emphasized that a significant impact on such a low score at the point P6 may be caused due to the evening time of measurement. The share of every group of vehicles on that stretch in question is likewise to the Wroclaw-Dresden route. The majority of counted vehicles $(60 \%)$ accounts for those with total GVM exceeding 12 tonnes. On the Dresden - Prague way, 8 petrol stations have been identified. Surprising as it may seem, they offer diesel oil (ON), gasoline with different octane number, fuel with bioadditives. On the four petrol stations LPG was available.

The third stretch was the route connecting Prague with Wroclaw, with the length of 280 $\mathrm{km}$. So as to leave Prague, one needs to go by the highway and then get off to the national road. This way on the Czech side leads through the hilly terrain with many bends. Due to this fact it is difficult to drive vehicles there, especially those with a weight exceeding 12 tonnes. As a consequence, there are often traffic congestions. The first measure at that section was taken just behind Prague (point P7) between 6:3am and 7:00am. A point P8 was located at the drive-in entry to Jelenia Gora. Vehicles at that point were being counted between 10:00am and 10:30am. The traffic there was small comparing to other points. The increase in traffic was recorded only at the point P9 in the vicinity of Strzegom (measured 11:30am-12:00 am). The increase in the number of vehicles could be explained by the fact that this area is abundant of granite mines. This type of raw materials is transported by trucks.

The last route is characterized by the lowest number of vehicles that are used for transport of goods (Figure 3). However, one should take into account that this route is unsuited for heavy duty vehicles with gross vehicle mass exceeding 3.5 tonnes. Divers of such vehicles usually chose other routes between Wroclaw and Prague, e.g. through Kłodzko or Liberec. 
As it is shown on Figure 4, the number of vehicles with GVM exceeding 12 tonnes is almost the same as delivery trucks. Contrary to the other measurement points, at the point P8 vehicles weighing up to 3.5 tonnes prevailed. There were 14 petrol stations located on this stretch with the possibility of fuelling diesel, gasoline, fuels with bioadditives and LPG.

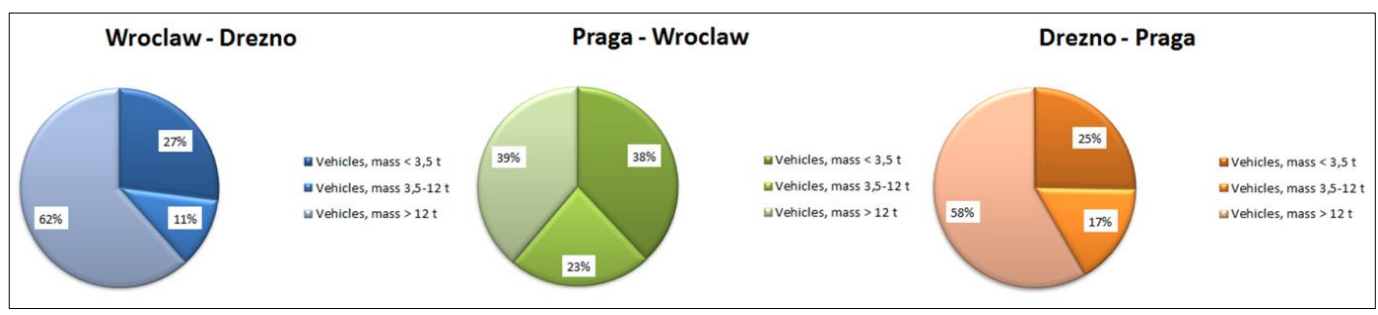

Figure 4 - The percentage share of groups of vehicles on the analysed routes

\section{The technical infrastructure of CNG stations for heavy-duty vehicles}

The natural gas as a fuel for motor vehicles is becoming more and more popular in the countries of the study. Germany is the country where CNG is the most popular and is willingly used by drivers. There are 913 petrol stations that offer this type of fuel (data for July 2016). In Poland there are only 26 publicly accessible stations, while in the Czech Republic there are $108[8,9]$.

Natural gas, which is dedicated to fuel vehicles, is compressed to 200-230 bar. The efficiency of the station plays an important role in fuelling since it has a direct effect on the fuelling time. The basic CNG station is equipped with:

- compressor,

- gas dehumidifier,

- cascade storage,

- steering and control devices,

- distributors.

Self-service petrol stations provide the opportunity to fill the fuel tank at the time comparable to the time of diesel fuelling. Cascade storages, where the compressed CNG is stored, ensure fast fuelling [10]. Another alternative is slow fuel filling stations where there are no cascade storages. The gas is compressed directly by the compressor. This is a much cheaper solution. Nevertheless, the fuelling is much slower and may take up to 8 hours.

While selecting a petrol station, one should specify some basic parameters that are suitable to a specific user group. In case of delivery truck fuelling the best solution is the combined station. It enables fast fuel filling and the opportunity to refuel at night, for instance during a driver's downtime. The station location is also very important factor. It should be selected in shortest possible way so as not to lose any extra time. The location of the CNG station is conditional upon the access to the gas network.

There were several CNG stations near the analysed routes. They were as follows:

- Wroclaw - Dresden route: Wroclaw, Legnica, Zgorzelec, Bautzen, Dresden

- Dresden - Prague route: Heidenau, Usti nad Labem, Prague (5 petrol stations)

- Prague - Wroclaw route: Prague, Milovice, Mlada Boleslav, Semily.

All aforementioned stations are located in the city centres. It means that in order to fuel the vehicle, the driver has to get off the planned route. Moreover, it forces to drive in the city center. 


\section{Summary and conclusions}

The study analysed the possibility of using natural gas as an alternative fuel for vehicles which moves on the Wroclaw - Dresden - Prague route. On every route 3 measurements points were specified. The traffic intensity of the trucks has been determined, as well as the number of petrol stations with the range of available fuels. The advantages of reduction of $\mathrm{CO}_{2}$ emissions into the atmosphere, as a result of the use of $\mathrm{CNG}$ in combustion engines, have been also evaluated. Moreover, the stations with CNG fuelling facilities have been designated near the routes of investigation.

Based on the gasoline, diesel and natural gas properties, the amount of carbon dioxide produced by the combustion of the particular fuel has been calculated. Table 1 shows the main characteristics of fuels and the amount of $\mathrm{CO}_{2}$ which was produced as a result of the combustion of $1 \mathrm{~kg}$ or $1 \mathrm{dm}^{3}$ of the single fuel.

Table 1 - Properties of selected fuels and the amount of $\mathrm{CO}_{2}$ produced by their combustion [7]

\begin{tabular}{|c|c|c|c|}
\hline Properties & Gasoline & Diesel & Natural gas \\
\hline Carbon content in $1 \mathrm{~kg}$ of fuel $[\mathrm{kg}]$ & 0.86 & 0.86 & 0.76000 \\
\hline Calorific value $[\mathrm{MJ} / \mathrm{kg}]$ & 43.00 & 43.00 & 47.70000 \\
\hline Density $\left[\mathrm{kg} / \mathrm{dm}^{3}\right]$ & 0.75 & 0.83 & 0.00071 \\
\hline $\begin{array}{c}\text { Amount of } \mathrm{CO}_{2} \text { from the } \\
\text { combustion of } 1 \mathrm{~kg} \text { of fuel }[\mathrm{kg}]\end{array}$ & 3.16 & 3.16 & 2.79000 \\
\hline $\begin{array}{c}\text { Amount of } \mathrm{CO}_{2} \text { from the } \\
\text { combustion of } 1 \mathrm{dm}^{3} \text { of fuel }[\mathrm{kg}]\end{array}$ & 2.37 & 2.62 & 0.00180 \\
\hline
\end{tabular}

In order to estimate the $\mathrm{CO}_{2}$ emissions on the analysed routes, length and estimated average fuel consumption for each group of tested vehicles have been assumed and it was: for vehicles $<3.5 \mathrm{t}-10.1 \mathrm{dm}^{3} / 100 \mathrm{~km}$ (diesel) and 11,7 (gasoline); $3.5-12 \mathrm{t}-21.3 \mathrm{dm}^{3} / 100 \mathrm{~km}$ (diesel); $>12 \mathrm{t}-37.8 \mathrm{dm}^{3} / 100 \mathrm{~km}$ (diesel). In case of delivery vehicles with the GVM not greater $3.5 \mathrm{t}$, it was assumed that $25 \%$ of this group of vehicles are equipped with sparkignition engines, while the rest is supplied with the diesel. The research took into account the brands and types of vehicles. Based on the above data and counted vehicles, the fuel consumption on particular route and then $\mathrm{CO}_{2}$ emission (Equation 1) have been estimated. Assuming that all of the counted vehicles would be powered by the natural gas, $\mathrm{CO}_{2}$ emissions on each route would be cut by at least $20 \%$

$$
\mathrm{CO}_{2}=\mathrm{N}_{r} \cdot \mathrm{G}_{r} \cdot \mathrm{CO}_{2, \text { fuel }}
$$

where: $\mathrm{CO}_{2}$ - the amount of $\mathrm{CO}_{2}$ produced along the entire route

$\mathrm{N}_{\mathrm{r}}$ - the number of vehicles on the road [pc.]

$\mathrm{G}_{\mathrm{r}}$ - the amount of fuel consumed by one vehicle on the route $\left[\mathrm{dm}^{3}\right]$

$\mathrm{CO}_{2 \text {,fuel }}$ - the amount of $\mathrm{CO}_{2}$ produced by the combustion of $1 \mathrm{dm}^{3}$ of fuel

Assuming that all of the counted vehicles would be powered by the natural gas, $\mathrm{CO}_{2}$ emissions on each route would be cut by at least $20 \%$. Figure 5 shows a comparison of the $\mathrm{CO}_{2}$ amount produced during the combustion of conventional fuels and combustion of $\mathrm{CNG}$ for each route. 


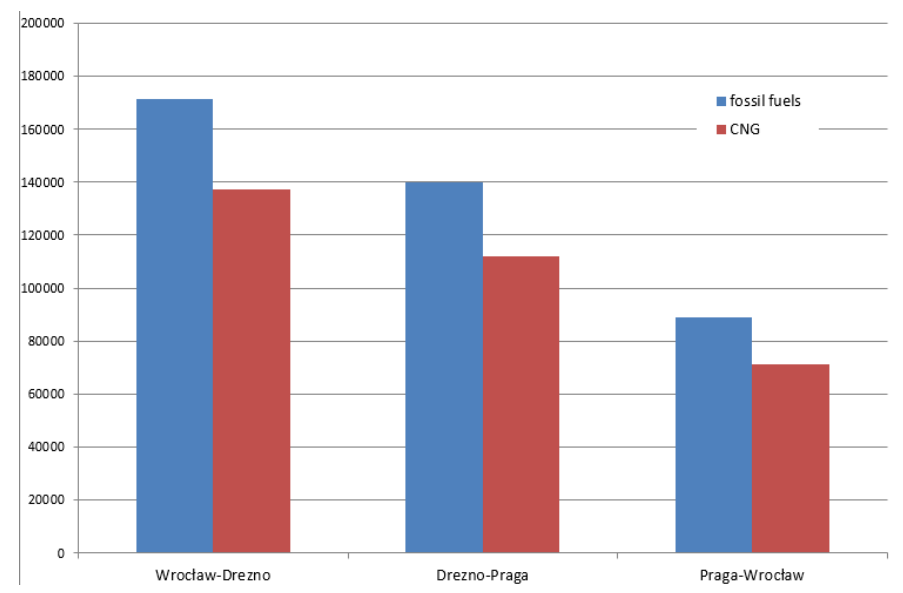

Figure 5 - The comparison of the $\mathrm{CO} 2$ amount produced during the combustion of petrol, diesel and natural gas

The analyses have shown that delivery vehicles have a significant environmental impact in the vicinity of the subjected routes. Supplying vehicles with CNG instead of conventional fuels would reduce $\mathrm{CO}_{2}$ emissions and consequently other pollutants. However, it will be possible only if the appropriate infrastructure is provided. The requirements include quickfill tank capabilities and close distance from transit routes. It is also crucial to ensure that a sufficient number of CNG stations are set so as to enable vehicles to cover the whole distance only with the natural gas (e.g. station location in every $100 \mathrm{~km}$ ).

\section{References}

1. Central Statistical Office, Transport. Activity results in 2015, Warsaw, Poland, (2016); Transport. Wyniki działalności w $2015 \mathrm{r}$.

2. Eurostat regional yearbook - 2016 edition, Luxembourg (2016)

3. Z. Chłopek, Protection of the natural environment, Wydawnictwo Komunikacji i Łączności, Warsaw, Poland (2002); Ochrona środowiska naturalnego

4. The National Centre for Emissions Management (KOBiZE), National Inventory Report 2016. Inventory of greenhouse gases in Poland for the years 1988-2014, Warsaw, Poland (2016)

5. J. Kast, R. Vijayagopal Jr. J.J. Gangloff, J. Marcinkoski, INT J HYDROGEN ENERG, 42, 4508-4517 (2017)

6. M. Kułażyński, Publication within the Project "The Development of the Potential and Academic Programmes of Wroclaw University of Technology", Automotive Engineering. Green fuels, Wroclaw University of Technology, Wroclaw, Poland (2011)

7. M.I. Khan, T. Yasmin, A. Shakoor, Ren. and Sus. En. Rev., 51, pp. 785-797 (2015)

8. NGVA Europe, the Natural \& bio Gas Vehicle Association, Vehicle catalogue, Brussel, Belgium (2016); http://www.ngva.eu/

9. https://cng.auto.pl/stacje-cng-w-polsce/ [access: 15.03.2017]

10. J. Sas, K. Kwaśniewski, Natural gas for vehicles, Uczelniane Wydawnictwa NaukowoDydaktyczne AGH, Cracow, Poland (2004)

11. K. Baczewski, T. Kałdoński, The fuels for diesel engines, Wydawnictwo Komunikacji i Łączności, Warsaw, Poland (2004); Paliwa do silników o zapłonie samoczynnym. 